\title{
PENGARUH PROMOSI, KUALITAS LAYANAN DAN BRAND PREFERENCE TERHADAP TINGKAT PENJUALAN PADA TOKO BINTANG TERANG MOTOR RANTAUPRAPAT
}

\author{
Junita $^{1}$, Ade Parlaungan Nasution ${ }^{2}$, Elida Florentina Sinaga Simanjorang ${ }^{3}$ \\ Fakutas Ekonomi dan Bisnis, Universitas Labuhan Batu, Sumatera Utara \\ Contact e-mail : junitayu23@gmail.com
}

\begin{abstract}
Penelitian ini bertujuan untuk menganalisis pengaruh promosi, kualitas layanan dan brand preference secara parsial dan simultan terhadap tingkat penjualan pada Toko Bintang Terang Motor. jenis penelitian ini adalah penelitian kuantitatif. Dengan populasi konsumen Toko Bintang Terang Motor dan diambil sampel yang berjumlah 97, dengan teknik Nonprobability Sampling yaitu Sampling Insidental. Teknik pengumpulan data yang digunakan adalah kuesioner. Uji instrument menggunakan uji validitas dan reabilitas. Teknik analisis yang digunakan adalah regresi berganda untuk menguji hipotesis penelitian. Hasil analisis menunjukkan bahwa promosi, kualitas layanan dan brand preference baik secara parsial maupun simultan berpengaruh positif dan signifikan terhadap tingkat penjualan pada Toko Bintang Terang Motor.
\end{abstract}

Kata Kunci: Promosi, Kualitas Layanan, Brand Preference, Tingkat Penjualan.

\section{LATAR BELAKANG MASALAH}

Bintang Terang Motor adalah sebuah toko sparepart sepeda motor yang terletak di Jalan Sirandorung Ujung No.25e, Rantauprapat, Labuhanbatu, Sumatera Utara. Di Rantauprapat sendiri toko sparepart sepeda motor tidaklah sedikit, Rantauprapat dapat dikatakan memiliki peluang besar pada jenis usaha ini karena pengguna sepeda motor di kota Rantauprapat dapat dikatakan banyak.

Namun, dikarenakan banyaknya pesaing, maka para pemiliki toko atau yang dikatakan sebagai penjual berusaha untuk memahami konsumen dan selalu mencari ide untuk dapat menarik ketertarikan para pelanggan agar dapat meningkatkan penjualan. Menurut Maqfira (2011) Volume penjualan merupakan jumlah total yangdihasilkan dari kegiatan penjualan barang. Semakin besar jumlah penjualan yang dihasilkan oleh perusahaan, semakin besar kemungkinan laba yang dihasilkan perusahaan. Oleh karena itu volume penjualan merupakan salah satu hal penting yang harus dievaluasi untuk kemungkinan perusahaan agar tidak rugi. Jadi volume penjualan yang menguntungkan harus menjadi tujuan utama perusahaan dan bukannya untuk kepentingan volume penjualan itu sendiri.

Salah satu ide tersebut ialah promosi. Hajid, dkk (2015) menyatakan bahwa promosi dilakukan untuk menarik minat pembeli terhadap barang atau jasa yang diperkenalkan. Promosi dapat dilakukan dengan berbagai cara, antara lain memasang spanduk, menyebarkan brosur, pameran dan sebagainya. Banyaknya cara promosi yang dilakukan oleh produsen, membuat konsumen lebih selektif dalam memilih barang yang akan dibeli. 
Ide lainnya ialah meningkatkan kualitas layanan, karena sebuah toko pasti memiliki karyawan yang akan melayani para pelanggannya. Sebuah bisnis dengan kualitas layanan yang tinggi maka akan memenuhi kebutuhan pelanggan, sementara sisanya secara kompetitif ekonomi. Menurut Yamit (2010) Kualitas layanan adalah sekelompok manfaat yang berdaya guna baik secara eksplisit maupun implisit atas kemudahan untuk mendapatkan barang maupun jasa layanan.

Menurut Tjiptono (2010) kualitas pelayanan adalah upaya penyampaian jasa untuk memenuhi kebutuhan dan keinginan pelanggan serta ketepatan penyampaian untuk mengimbangi harapan pelanggan, dimana harapan pelanggan merupakan keyakinan konsumen sebelum mencoba atau membeli suatu produk yang dijadikan acuan dalam menilai kinerja produk tersebut. Maka Peningkatan kualitas layanan juga dapat meningkatkan daya saing ekonomi.

Dalam penjualan sebuah produk, pasti akan kita temui dalam berbagai merek. Sebahagian konsumen juga sudah dapat menilai baik buruknya sebuah merek. Maka Ide ketiga yang juga merupakan ide terakhir untuk meningkatkan minat beli pelanggan ialah brand preference atau yang juga disebut sebagai preferensi merek. Preferensi merupakan kecenderungan akan sesuatu yang biasanya diperoleh setelah konsumen membandingkan sesuatu tersebut dengan yang lainnya.

Dengan demikian Brand Preference merupakan kecenderungan seorang konsumen untuk menyukai sebuah merek dibandingkan yang lainnya sehingga akan membentuk keinginannya untuk membeli merek tersebut. Brand Preference dihasilkan dari perbandingan atau penilaian sebuah merek relative terhadap merek yang lainnya. Jika merek tersebut memiliki kepribadian yang sesuai atau memberikan nilai yang optimal maka konsumen akan cenderung menyukai merek tersebut (Fongana, 2009).

Konsumen bukan hanya seorang Raja, melainkan segala-galanya bagi produsen, distributor maupun penjual dalam konteks ekonomi. Oleh karena itu, apa saja yang diminati ataupun disukai oleh konsumen harus dapat dipenuhi untuk mendapat minat beli dari para konsumen tersebut. Maka dari semua masalah yang ada, penulis mengangkat judul "Pengaruh Promosi, Kualitas Layanan, dan Brand Preference terhadap Tingkat Penjualan Toko Bintang Terang Motor Rantauprapat".

\section{LANDASAN TEORI}

\section{Promosi}

Pengertian promosi menurut Kotler dan Armstrong (2012), "Promotion means activities that communicate the merits of the product and persuade target customers to buy it", artinya promosi merupakan kegiatan yang mengomunikasikan manfaat dari sebuah produk dan membujuk target konsumen untuk membeli produk tersebut. Kotler dan Armstrong (2012) juga mengemukakan nahwa bauran promosi terdiri atas 5 alat-alat promosi, yaitu:

1. Advertising (Periklanan), yaitu semua bentuk presentasi dan promosi nonpersonal yang dibayar oleh sponsor untuk mempresentasikan gagasan, barang atau jasa. Periklanan dianggap sebagai manajemen citra yang bertujuan menciptakan dan memelihara cipta dan makna dalam benak konsumen. Bentuk promosi yang digunakan mencakup broadcast, print, outdoor, internet, dan bentuk lainnya. 
2. Sales Promotion (Promosi Penjualan), yaitu insentif-insentif jangka pendek untuk mendorong pembelian atau penjualan suatu produk atau jasa. Bentuk promosi yang digunakan mencakup discounts, coupons, displays, demonstrations, contests, sweepstakes, dan events.

3. Personal Selling (Penjualan Perseorangan), yaitu presentasi personal oleh tenaga penjualan dengan tujuan menghasilkan penjualan dan membangun hubungan dengan konsumen. Bentuk promosi yang digunakan mencakup presentations, trade shoes, dan incentive programs.

4. Public Relations (Hubungan Masyarakat), yaitu membangun hubungan yang baik dengan berbagai perusahaan supaya memperoleh publisitas yang menguntungkan, membangun citra perusahaan yang bagus dan menangani atau meluruskan rumor, cerita, serta event yang tidak menguntungkan. Bentuk promosi yang digunakan mencakup press releases, sponsorships, special events dan web pages.

5. Direct Marketing (Penjualan Langsung), yaitu hubungan langsung dengan sasaran konsumen dengan tujuan untuk memperoleh tanggapan segera dan membina hubungan yang abadi dengan konsumen. Bentuk promosi yang digunakan mencakup catalogs, telephone marketing, kiosks, mobile marketing, internet dan lainnya.

\section{Kualitas Layanan}

Menurut Tjiptono (2010) kualitas pelayanan adalah upaya penyampaian jasa untuk memenuhi kebutuhan dan keinginan pelanggan serta ketepatan penyampaian untuk mengimbangi harapan pelanggan, dimana harapan pelanggan merupakan keyakinan konsumen sebelum mencoba atau membeli suatu produk yang dijadikan acuan dalam menilai kinerja produk tersebut.

Indikator kualitas layanan menurut Tjiptono (2010) :

1. Tangibles (Bukti Langsung), meliputi fasilitas fisik, perlengkapan, pegawai dan sarana komunikasi.

2. Reliability (Keandalan), yaitu kemampuan memberikan pelayanan yang dijanjikan dengan segera, akurat dan memuaskan.

3. Responsiveness (Daya Tanggap), yaitu keinginan dan kesediaan para karyawan untuk membantu para pelanggan dan memberikan pelayanan dengan tanggap.

4. Assurance (Jaminan), mencakup pengetahuan, kemampuan, kesopanan dan sifat dapat dipercaya yang dimiliki para karyawan, bebas dari bahaya dan risiko atau keragu-raguan.

5. Emphaty (Empati), meliputi kemudahan dalam menjalin hubungan, komunikasi yang baik dan efektif, perhatian personal dan pemahaman atas kebutuhan individual para pelanggan.

\section{Brand Preference}

Brand preference disebut juga Preferensi merek dalam bahasa Indonesia, merupakan kecenderungan seorang konsumen untuk menyukai sebuah merek dibandingkan yang lainnya sehingga akan membentuk keinginan untuk membeli merek tersebut (Halim dkk., 2014).

Menurut Chintia (2014) preferensi merek dapat diukur dengan indikator:

1. Lebih menyukai merek tertentu daripada merek lain.

2. Merek tertentu menjadi pilihan diantara semua merek.

3. Akan cenderung membeli merek tertentu diantara merek lain.

4. Akan lebih menggunakan merek tertentu daripada merek lain.

5. Merek tertentu menarik bagi konsumen. 


\section{Tingkat Penjualan}

Volume penjualan merupakan jumlah total yang dihasilkan dari kegiatan penjualan barang. Semakin besar jumlah penjualan yang dihasilkan oleh perusahaan, semakin besar kemungkinan laba yang dihasilkan perusahaan. Oleh karena itu volume penjualan merupakan salah satu hal penting yang harus dievaluasi untuk kemungkinan perusahaan agar tidak rugi. Jadi volume penjualan yang menguntungkan harus menjadi tujuan utama perusahaan dan bukannya untuk kepentingan volume penjualan itu sendiri (Maqfira, 2011).

Menurut Abdul Halim dan Karnadi (2016), kegiatan penjualan dipengaruhi oleh beberapa faktor sebagai berikut :

1. Kondisi Dan Kemampuan Penjual

Transaksi jual-beli pada prinsipnya melibatkan dua pihak, yakni penjual sebagai pihak pertama dan pembeli sebagai pihak kedua.

2. Kondisi Pasar

Pasar yang dimaksud dalam hal ini yaitu sekelompok pembeli atau pihak yang menjadi sasaran dalam penjualan.

3. Modal

Modal sangatlah diperlukan dalam kondisi/ keadaan produk belum dikenal dan lokasi pembeli jauh dari tempat penjual. Untuk memperkenalkannya penjual membawa barangnya ke tempat pembeli.

4. Kondisi Organisasi Perusahaan

Pada perusahaan besar biasanya masalah penjualan ditangani oleh bagian penjualan yang dipegang oleh orang-orang ahli dibidang penjualan. Sebaliknya, pada perusahaan kecil, masalah penjualan ditangani sendiri oleh pimpinan dan tidak diberikan kepada orang lain.

5. Faktor Lain

Faktor-faktor lain seperti pemberian potongan harga, komisi dan sebagainya sering mempengaruhi penjualan.

\section{METODOLOGI PENELITIAN}

\section{Jenis penelitian}

Jenis penelitian yang digunakan adalah statistik deskriptif yang digunakan untuk menganalisis dan menyajikan data kuantitatif dengan tujuan untuk mengetahui gambaran perusahaan yang dijadikan sampel penelitian.

\section{Jenis Data}

Jenis data dalam penelitian ini adalah data primer yang berupa data kuesioner yang telah diisi oleh konsumen Toko Bintang Terang Motor.

\section{Metode Analisis}

Metode analisis kuantitatif adalah suatu metode penelitian untuk menghasilkan data yang berbentuk angka atau bilangan. Sesuai dengan bentuknya, metode analisis kuantitatif dapat diolah atau di analisis menggunakan teknik perhitungan matematika atau statistika. 


\section{Teknik Pengumpulan Data}

1. Wawancara

Wawancara adalah proses memperoleh keterangan untuk tujuan penelitian dengan cara tanya jawab sambil bertatap muka antara si penanya atau pewawancara dengan si penjawab atau responden dengan menggunakan alat yang dinamakan interview guide (panduan wawancara).

2. Studi Pustaka

Studi Pustaka merupakan metode pengumpulan data dan informasi dengan melakukan kegiatan kepustakaan melalui buku-buku, jurnal, penelitian terdahulu dan lain sebagainya yang berkaitan dengan penelitian yang sedang dilakukan.

3. Kuesioner

Kuesioner merupakan teknik pengumpulan data yang dilakukan dengan cara member seperangkat pertanyaan atau pernyataan tertulis kepada responden untuk dijawabnya (Sugiyono, 2012). Pertanyaan yang di ajukan pada responden harus jelas dan tidak meragukan responden. Dengan melakukan penyebaran kuesioner untuk mengukur persepsi responden digunakan Skala Likert yang dikembangkan oleh Rensis Likert. Skala Likert umumnya menggunakan 5 angka penelitian, yaitu: (1) sangat setuju, (2) setuju, (3) netral, (4) tidak setuju dan (5) sangat tidak setuju. Urutan setuju atau tidak setuju dapat dibalik mulai dari sangat tidak setuju sampai dengan sangat setuju (Indriantoro dan Supomo, 2014).

4. Observasi

Observasi adalah pengamatan dan juga pencatatan sistematik atas unsur-unsur yang muncul dalam suatu obyek penelitian. Observasi sebagai teknik pengumpulan data mempunyai ciri yang spesifik bila dibandingkan dengan teknik yang lain, yaitu wawancara dan kuesioner. Kalau wawancara dan kuesioner selalu berkomunikasi dengan orang, maka observasi tidak terbatas pada orang, tetapi juga obyek-obyek alam yang lain (Sugiyono, 2012).

\section{HASIL PENELITIAN DAN PEMBAHASAN}

Dari hasil pengujian hipotesis secara parsial menunjukkan promosi berpengaruh positif dan signifikan terhadap tingkat penjualan pada Toko Bintang Terang Motor Rantauprapat, yang ditunjukkan pada nilai $t_{\text {hit }}(3,129)>t_{\text {tabel }}(1,661)$ dengan taraf signifikansi $0,002<0,05$. Konsumen menilai promosi toko cukup baik dan menjadi tertarik untuk berbelanja serta memperbaiki sepeda motornya pada toko bintang terang motor. karena menurut Kuncoro (2010) promosi merupakan salah satu hal yang menunjang keberhasilan penjualan, yang juga digunakan perusahaan untuk memperkenalkan produk kepada masyarakat luas.

Variabel kualitas layanan secara parsial juga berpengaruh positif dan signifikan terhadap tingkat penjualan pada Toko Bintang Terang Motor, yang tunjukkan pada nilai $t_{\text {hit }}$ $(3,610)>t_{\text {tabel }}(1,661)$ dengan taraf signifikansi $0,000<0,05$. Konsumen menilai pelayanan pada toko bintang terang motor sangat memuaskan serta staff toko bintang terang motor memiliki sopan santun yang baik. Dimana menurut Yamit (2010) kualitas layanan adalah sekelompok manfaat yang berdaya guna baik secara eksplisit maupun implisit atas kemudahan untuk mendapatkan barang maupun jasa layanan. 
Variabel Brand Preference secara parsial juga berpengaruh positif dan signifikan terhadap tingkat penjualan pada toko bintang terang motor, yang tunjukkan pada nilai $t_{\text {hit }}$ $(2,398)>t_{\text {tabel }}(1,661)$ dengan taraf signifikansi $0,018<0,05$. Dengan sparepart suku cadang sebagai pembanding dengan sparepart biasa, konsumen menilai sparepart suku cadang memiliki kualitas tiada banding dan lebih terjamin ketahanannya shingga mereka lebih tertarik. Biasanya preferensi merek dihasilkan dari pengalaman menyenangkan terhadap merek tersebut, jika mengalami ketidaksukaan maka konsumen akan beralih ke merek lain (Juhan Tanjung, 2013).

Dan secara simultan, promosi, kualitas layanan, dan brand preference secara bersamasama juga menunjukkan adanya pengaruh positif dan signifikan terhadap tingkat layanan pada toko bintang terang motor, yang ditunjukkan pada nilai $F_{\text {hit }}(119,765)>F_{\text {tabel }}(2,70)$ dengan probabilitas $0,000<0,05$.

Hasil uji determinasi menunjukkan bahwa tingkat penjualan dapat dijelaskan oleh promosi, tingkat penjualan dan brand preference sebesar $78,8 \%$ sedangkan sisanya $21,2 \%$ dapat dijelaskan oleh faktor-faktor lain yang tidak diteliti dalam penelitian ini.

\section{KESIMPULAN}

1. Promosi berpengaruh positif dan signifikan secara parsial terhadap tingkat penjualan pada Toko Bintang Terang Motor Rantauprapat, yang ditunjukkan pada nilai $t_{\text {hit }}(3,129)>t_{\text {tabel }}$ $(1,661)$ dengan taraf signifikansi $0,002<0,05$.

2. Tingkat layanan berpengaruh positif dan signifikan secara parsial terhadap tingkat penjualan pada Toko Bintang Terang Motor Rantauprapat, yang ditunjukkan pada nilai $t_{\text {hit }}$ $(3,610)>t_{\text {tabel }}(1,661)$ dengan taraf signifikansi $0,000<0,05$.

3. Variabel Brand Preference berpengaruh positif dan signifikan secara parsial terhadap tingkat penjualan pada Toko Bintang Terang Motor, yang tunjukkan pada nilai $t_{\text {hit }}(2,398)$ $>\mathrm{t}_{\text {tabel }}(1,661)$ dengan taraf signifikansi $0,018<0,05$.

4. Promosi, kualitas layanan dan brand preference secara simultan berpengaruh positif dan signifikan terhadap tingkat penjualan pada Toko Bintang Terang Motor, yang ditunjukkan pada nilai $F_{\text {hit }}(119,765)>F_{\text {tabel }}(2,70)$ dengan probabilitas $0,000<0,05$.

5. Promosi, tingkat penjualan dan brand preference sebesar $78,8 \%$ sedangkan sisanya $21,2 \%$ dapat dijelaskan oleh faktor-faktor lain yang tidak diteliti dalam penelitian ini.

6. Variabel yang dominan mempengaruhi tingkat penjualan pada Toko Bintang Terang Motor Rantauprapat adalah variabel kualitas layanan.

\section{DAFTAR PUSTAKA}

Siagian, Hotlan dan Edwin Cahyono. 2014. “Analisis Website Quality, Trust Dan Loyalty Pelanggan Online Shop”. Jurnal Manajemen Pemasaran, Fakultas

Ekonomi Universitas Kristen Petra. Vol. 8, No. 2, Oktober 2014.

Halim, Beatrice Clementia dkk. 2014. "Pengaruh Brand Identity terhadap timbulnya Brand Preference dan Repurchase Intention pada Merek Toyota". Jurnal Manajemen Pemasaran. Fakultas Ekonomi Kristen Petra. Vol. 2, No. 1. November 2014.

Tanjung, Halim A. 2013. "Pengaruh Harga, Citra Merek Dan Personalitas Merek Terhadap Preferensi Merek Pada Laptop Hewllet Packard (HP)". Artikel ilmiah. Sekolah Tinggi Ilmu Ekonomi Perbanas, Surabaya. 
M.Hajid, dkk. 2015. Buku Master SMP/MTS : Ringkasan Materi \& Kumpulan Rumus Lengkap. Depok : Puspa Swara.

Alyas, Rano dkk. 2016. "Kualitas Layanan" https://id.wikipedia.org/wiki/Kualitas_layanan. Diakses 28 Februari 2019.

Suryana, Cahya. 2010. "Data Dan Jenis Data Penelitian". https://csuryana.wordpress.com/2010/03/25/data-dan-jenis-data-penelitian/

Diakses 20 Februari 2019.

Karya Tulisku. 2016. "Teknik Pengumpulan Data (Wawancara,Angket dan Observasi)". https://karyatulisku.com/2016/04/teknik-pengumpulan-datawawancara.html?m=1. Diakses 8 Maret 2019.

Sugiyono. 2012. Metode Penelitian Bisnis. Bandung : Alfabeta.

Sugiyono. 2013. Statistika untuk Penelitian. Bandung : Alfabeta.

Resmi, Siti. 2017. Perpajakan: Teori dan Kasus (Edisi 10). Jakarta : Salemba Empat.

Indriantoro, Nur dan Bambang Supomo. 2014. Metode Penelitian dan Bisnis. Yogyakarta: BPFE.

Ghozali, Imam. 2016. Desain Penelitian Kuantitatif dan Kualitatif, untuk Akuntansi Bisnis, dan Ilmu Sosial Lainnya. Semarang : Yoga Pratama.

Kotler, Philip dan Gary Armstrong. 2012. Prinsip-prinsip Pemasaran. Jakarta: Erlangga.

Alma, Buchari. 2013. Manajemen Pemasaran dan Pemasaran Jasa. Bandung : Alfabeta.

Kuncoro, Mudrajad. 2010. Masalah, Kebijakan dan Politik, Ekonomika Pembangunan. Jakarta : Erlangga.

Tjiptono, Fandy. 2010. Manajemen Jasa Edisi kedua. Yogyakarta : Andi Offset.

Setiadi,Nugroho J. 2013. Prilaku Konsumen, Edisi Revisi. Jakarta : PT. Kharisma Putra Utama.

Arikunto, Suharsimi. 2013. Prosedur Penelitian Suatu Pendekatan Praktik. Jakarta : Rineka Cipta.

Kumala, Octavianika Benazir. 2012. Pengaruh World Of Mouth Terhadap Minat Beli Konsumen Pada Tune Hotels Kuta Bali. Skripsi. Universitas Indonesia, Jakarta.

Arumsari, Dheany. 2012. Analisis Pengaruh Kualitas Produk, Harga Dan Promosi Terhadap Keputusan Pembelian Air Minum Dalam Kemasan (ADMK) Merek Aqua. Skripsi. Universitas Diponegoro, Semarang.

Riduwan dan Akdon. 2015. Rumus Dan Data Dalam Analisis Statistika. Bandung : Alfabeta. 
Rudianto. 2009. Pengantar Akuntansi. Jakarta : Erlangga.

Rangkuti, Freddy. 2009. Strategi Promosi Yang Kreatif, Edisi Pertama. Jakarta : Gramedia Pustaka Utama

Utami, Maqfira Dwi. 2011. Analisis Pengaruh Harga Dan Promosi Terhadap Peningkatan Penjualan Tiket Pada PT. Maniela Tour \& Travel Di Makassar. Skripsi. Universitas Hasanuddin, Makassar.

Swastha, Basu. 2010. Manajemen Penjualan, Edisi Ketiga . Yogyakarta : BPFE.

Halim, Abdul dan Karnadi. 2016. Pengaruh Bauran Pemasaran Terhadap Tingkat Penjualan Kerupuk Pada UD. Subandi Rogojampi Banyuwangi. Jurnal Manajemen Pemasaran. Universitas Andurachman Saleh, Situbondo.

Dewi, Chintia Anggar. 2014. "Pengaruh Nama Merek Terhadap Kesadaran Merek Dan Preferensi Merek Minuman Sari Buah Dalam Kemasan”. Jurnal Ilmu Manajemen, Fakultas Ekonomi Universitas Negeri Surabaya. Vol. 2, No. 4, Oktober 2014. 